\title{
When the venerid clam Tapes decussatus is parasitized by the protozoan Perkinsus sp. it synthesizes a defensive polypeptide that is closely related to p225
}

\author{
Juan F. Montes, Mercè Durfort, José García-Valero* \\ Departament de Biologia Cel-lular Animal i Vegetal, Facultat de Biologia, Universitat de Barcelona, Avda. Diagonal, 647, \\ E-08028 Barcelona, Spain
}

\begin{abstract}
Molluscs, like other invertebrates, have primitive defense systems. These are based on chemotaxis, recognition and facultative phagocytosis of foreign elements. Previously, we have described one of these systems: a cellular reaction involving infiltrated granulocytes against Perkinsus sp. parasitizing the Manila clam Tapes semidecussatus, in which the parasites are encapsulated by a defensive host product, the polypeptide p225. The aim of this study is to determine the similarities between the defense mechanisms of 2 venerid clams, $T$ semidecussatus and $T$. decussatus, when they are infected by Perkinsus sp. The hemocytes of both species infiltrate the connective tissue, redifferentiate, and ultimately, express and secrete the polypeptide which constitutes the main product of the capsule that surrounds the parasites. The main secretion product of $T$. decussatus shows a high degree of homology to that of $T$ semidecussatus, since it has a similar electrophoretic mobility and the polypeptide is recognized by the polyclonal serum against p225 from $T$. semidecussatus, as confirmed by Western blotting and immunocytochemistry. In conclusion, we demonstrate the existence of 2 polypeptides that are closely related at the molecular and functional level, and are specific in the defense of some molluscs against infection by these protozoan parasites.
\end{abstract}

KEY WORDS: Defense mechanisms - Encapsulation - Granulocytes · Parasitism - Perkinsus sp. Tapes decussatus Tapes semidecussatus - Veneridae

\section{INTRODUCTION}

Protozoa belonging to the genus Perkinsus (formerly Dermocystidium or Labyrinthomyxa) (Apicomplexa, Perkinsea) (Levine 1978) have been described as disease agents in 63 species of bivalves and 4 species of gastropods (Perkins 1993). In Europe, during the last 10 yг, Perkinsus spp. trophozoites have been associated with mass mortalities of commercially important venerid clams of the genus Tapes (=Ruditapes = Venerupis) (Mollusca, Bivalviaj, such as the indigenous species $T$. decussatus (Da Ros \& Canzonier 1985, Chagot et al. 1987, Comps \& Chagot 1987, González et al. 1987, Villalba \& Navas 1988, Azevedo 1989,

\footnotetext{
- Addressee for reprint requests

E-mail: josepg@porthos.bio.ub.es
}

Figueras et al. 1992, Goggin 1992, Navas et al. 1992) and the introduced species $T$. semidecussatus $(=T$. philippinarum $=T$ japonica) (Villalba \& Navas 1988, Sagristà et al. 1991, 1995, Goggin 1992, Navas et al. 1992, Montes et al. 1995a).

Recently, Bachère et al. (1995) have reviewed the defense mechanisms that are present in bivalve molluscs. There is general agreement that the molluscs have cellular effectors and immune mechanisms. However, it is necessary to consider that, whereas vertebrates have an immune system, invertebrates have more primitive defense systems, which often rely chiefly on phagocytic cells (Alberts et al. 1994). Those immune mechanisms are based on chemotaxis and recognition of foreign elements by lectin-like molecules, and subsequent phagocytosis. However, Chintala et al. (1994) concluded that serum agglutinins, the putative lectin-like molecules, did not play a role in 
oyster defense against Perkinsus marinus or Haplosporidium nelsoni.

In the venerid clams, Tapes semidecussatus and $T$. decussatus, Perkinsus spp. parasitism activates the host defense mechanisms and provokes an inflammatory response based on the infiltration of hemocytes, the cellular effectors. In the butterfish (also named carpet-shell) clam $T$. decussatus from Portugal, Comps \& Chagot (1987) and Chagot et al. (1987) reported an inflammatory reaction constituted by granulocytes causing the encapsulation of the trophozoites by a periodic Acid-Schiff (PAS) positive substance. Recently, we have described a similar cellular reaction, involving infiltrated granulocytes, against this pathogen in the Manila (also named Japanese littleneck) clam 1. semudecussatus from the Spanish Mediterranean coast. This cellular reaction is polarized. The trophozoites are encapsulated by the secretory product which is released after the death of the granulocytes that are closest to the parasites (Montes et al. 1995a). The main component of this specific defense product is a slightly glycosylated polypeptide of about $225 \mathrm{kDa}$ (p225). Moreover, the absence of this polypeptide in non-parasitized Manila clam indicates the exclusive association of p225 with the parasitosis (Montes et al. 1995b).

The aim of the present study is to determine the similarities between 2 Tapes species ( $T$. semidecussatus and $T$. decussatus) in relation to their defense mechanisms. Our purpose is to correlate the main component of the cellular reaction at both cellular (infiltrated granulocytes) and molecular (secretory product) levels. The results allow us to establish a high homology between the cellular reactions of these closely related molluscan species against Perkinsus sp. parasitism.

\section{MATERIALS AND METHODS}

Animals. Specimens of parasitized and non-parasitized clams Tapes decussatus and $T$. semidecussatus were collected in the delta of the River Ebro, Tarragona (NE Spain), at the Mediterranean Sea.

Gill tissue processing. Abscesses from parasitized gills of Tapes decussatus and T. semidecussatus, isolated under a stereoscopic microscope, and non-parasitized gills of $T$. decussatus were prepared for SDSPAGE and Western blot as previously described (Montes et al. 1995b).

SDS-PAGE and Western blot. SDS-PAGE was performed as described by Laemmli (1970) in 9\% acrylamide gels under reducing conditions. Polypeptides were resolved by silver staining according to the method of Merril et al. (1981). Western blot analysis was performed following Towbin et al. (1979). After
SDS-PAGE, polypeptides were transferred to nitrocellulose membranes. Transfer was realized at $15 \mathrm{~V}$ for $2 \mathrm{~h}$ in a Trans-blot semi-dry transfer cell (Bio Rad, Richmond, CA, USA). Membranes were blocked with 10\% non-fat dried milk in TBST [10 mM Tris- $\mathrm{HCl}(\mathrm{pH}=8)$, $150 \mathrm{mM} \mathrm{NaCl}, 0.05 \%$ Tween 20] for $30 \mathrm{~min}$ and then incubated with the polyclonal serum against p225 from Tapes semidecussatus (diluted 1:800 in TBST with 10\% non-fat dried milk) (Montes et al. 1995b) overnight at $4^{\circ} \mathrm{C}$. After 3 washes in TBST the membranes were incubated with peroxidase-conjugated swine anti-rabbit IgG (Dako, Glostrup, Denmark) for $2 \mathrm{~h}$ at room temperature. After washing, the membranes were developed in a substrate solution of 3,3'-diaminobenzidine tetrahydrochloride $(D A B$; Sigma Chemical Co, St. Louis, MO, USA) ds chinunuğen, and finally recorded on Technical Pan film (Kodak, Hemel Hempstead, UK).

Immunocytochemistry. Abscesses from parasitized gills (Tapes decussatus and $T$. semidecussatus) were fixed in $4 \%$ paraformaldehyde and $0.1 \%$ glutaraldehyde in $0.1 \mathrm{M}$ phosphate-buffered saline (PBS). Samples were prepared for Lowicryl K4M resin embedding (Chemische Werke Lowi, Waldkraiburg, Germany) following Carlemalm et al. (1982). Immunolabeling for p225 was achieved as previously described (Montes et al. 1995b). In brief, the grids were incubated with serum against p225 (1:3000 dilution), and then bound polyclonal antibodies were visualized following incubation with $10 \mathrm{~nm}$ or $15 \mathrm{~nm}$ protein A gold (pAg; Sigma). Finally, thin sections were observed with a Reichert-Jung Polyvar 2 optical microscope and the ultrathin sections were examined on a Hitachi H-600 $A B$ transmission electron microscope.

Quantitative evaluation. The label density (LD) was estimated as the number of gold particles per sectioned area of granules and capsule profiles. The area parameter was estimated by stereological methods (Weibel 1979) and significance of mean differences between experimental groups was tested by ANOVA.

\section{RESULTS}

\section{Histological examination}

Light microscopy of semi-thin sections of gill abscesses from the butterfish clam Tapes decussatus revealed the presence of trophozoites of Perkinsus sp. in the connective tissue. Parasites, isolated or grouped, were surrounded by closely packed granulocytes, which constituted the cellular reaction of this organism against Perkinsus sp. trophozoites. Parasites were seen totally or partially encapsulated by a dense homogeneous substance, giving rise to the formation of cysts (Fig. 1). 


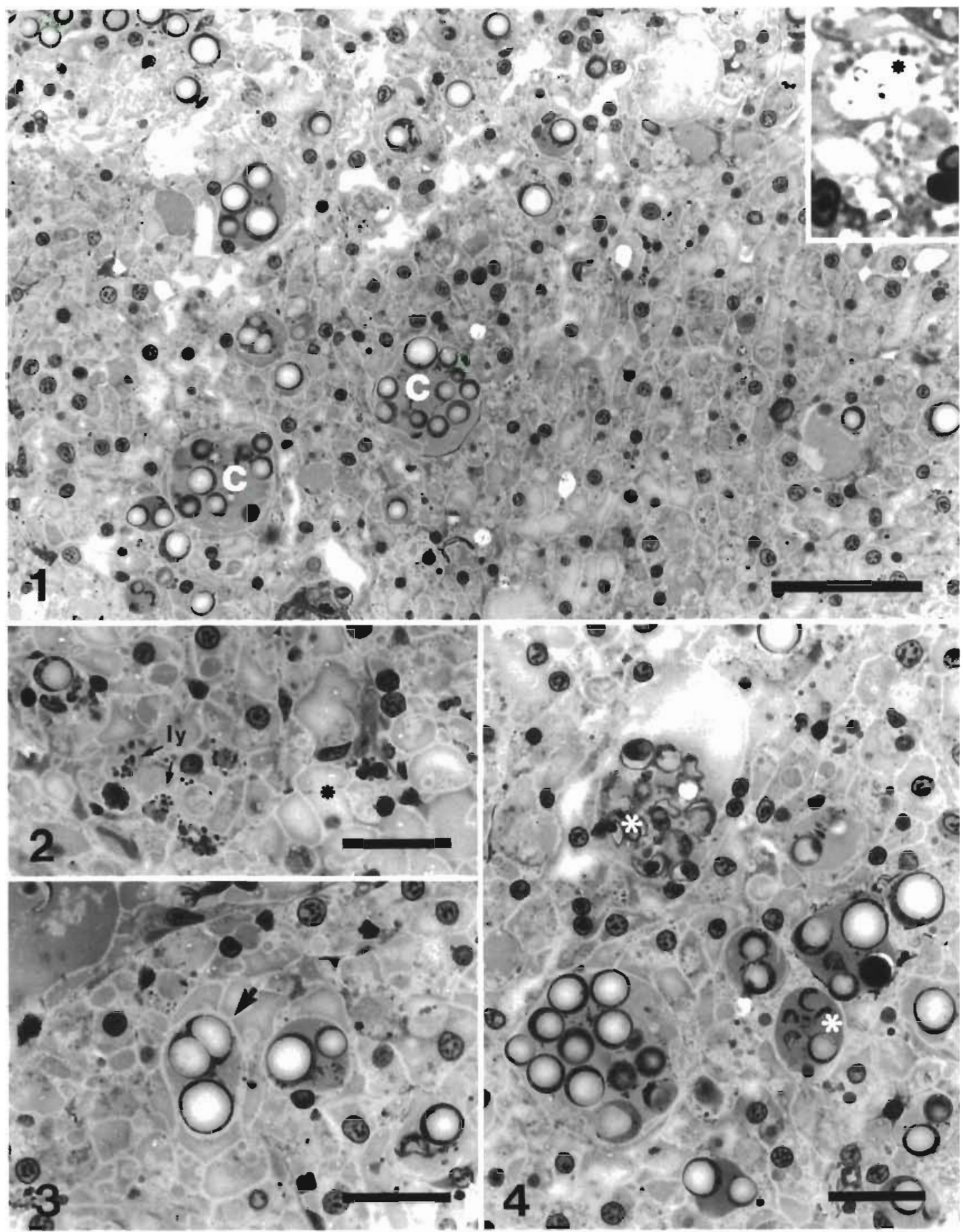

Figs. 1 to 4. Tapes decussatus parasitized by Perkinsus sp. trophozoites. Lowicryl semithin sections from gills of the clam. Fig. 1. Closely packed granulocytes constitute the only cell type observed in the cellular reaction against the parasites. Cysts (c) consist of a variable number of trophozoites and the capsule, which surrounds the parasites totally or partially. $\times 470$. Scale bar $=$ $50 \mu \mathrm{m}$. Fig. 1 inset. Mitotic figure from an infiltrated granulocyte of the cellular reaction (asterisk). $\times 1325$. Fig. 2 . Cytoplasm gelation (asterisk) and lysosomes (ly) in some granulocytes. $\times 830$. Scale bar $=20 \mu \mathrm{m}$. Fig. 3. Trophozoite proliferation by binary fission in a cyst (arrow). $\times 810$. Scale bar $=20 \mu \mathrm{m}$. Fig. 4. Cysts containing a variable number of trophozoites. Some dead trophozoites are seen in several cysts (asterisks). $\times 720$. Scale bar $=20 \mu \mathrm{m}$ 
Infiltrated granulocytes constituted the only cell type observed in the cellular reaction, which was organized as a single cellular mass without cells or fibers from connective tissue. Moreover, processes of cell division were occasionally observed in these infiltrated cells (Fig. 1 inset). Granulocytes showed a variable profile and diameter, with the cytoplasm filled by granules. Lysosomes were recognized as dense granules (Fig. 2). Furthermore, cytoplasm condensation in a single, undifferentiated mass was observed in some granulocytes (Figs. 2, $3 \& 4$ ). The nuclei were circular in section and often situated eccentrically. Abundant clots of heterochromatin were located in the nucleoplasm, whereas peripheral heterochromatin was scarce (Figs. 1, 2, 3 \& 4).

Cysts contained one to severai trophozoites surrounded by a non-cellular, non-fibrillar capsule. Uninucleated trophozoites were characterized by the presence of a vacuole that occupied up to $90 \%$ of the cell volume. Parasites were circular in section with a diameter ranging between 5 and $12 \mu \mathrm{m}$ (Fig. 1). In some instances, trophozoite division by binary fission was noticed (Fig. 3). On the other hand, dead trophozoites were also seen in the cysts, which appeared as damaged cells with dense cytoplasm, shrunken aspect and spindle shape (Fig. 4).

\section{Western blotting}

Incubation with the serum against p225 revealed a band of about $225 \mathrm{kDa}$ in the Western blots from gill abscesses from Tapes decussatus (Fig. 5). No apparent differences were observed between these 2 clam species in molecular weight or in antibody recognition of the polypeptide. The band was not detected in the lane corresponding to the non-parasitized gills.

\section{Immunolocalization}

By electron microscopy, granulocytes of the cellular reaction in Tapes decussatus were characterized by the presence of numerous secretory membrane-bound granules with a homogeneous content (Figs. 6, 7 \& 8) and large mitochondria with tubular cristae and an extended matrix (Fig. 6). The granulocyte cytoplasm also showed a well-developed endomembranous compartment distributed in 2 populations: round cisternae and vesicular-tubular saccules, the former related to the rough endoplasmic reticulum and the latter to the Golgi apparatus and the endosomal pathway (Fig. 7). Moreover, autophagosomes derived from granules were occasionally seen, which showed a heterogeneous content with internal membranes and residual bodies (Fig. 8).

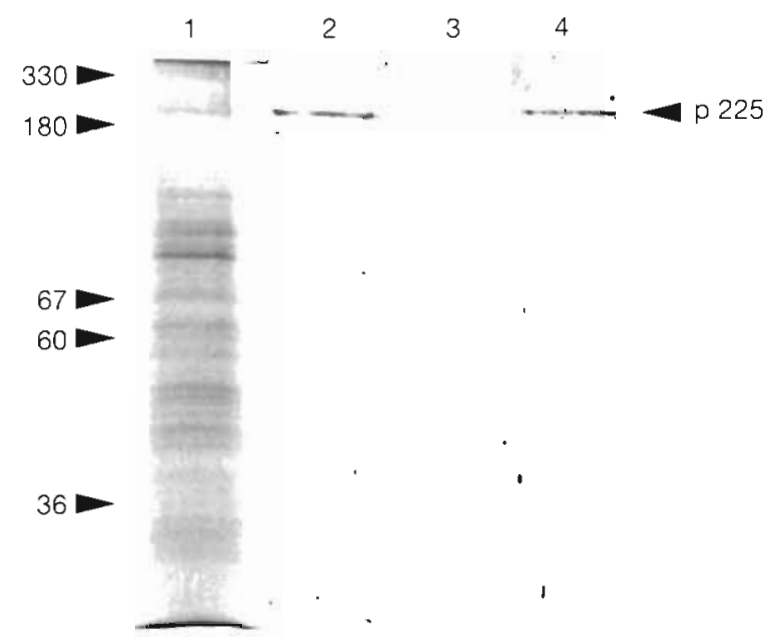

Fig. 5. Lane 1: SDS-PAGE of abscesses from Perkinsus sp.parasitized gills of Tapes decussatus. Lanes 2 to 4: Western blotting with the serum against p225 from $T$. semidecussatus. Lane 2: abscesses from parasitized gills of $T$. decussatus; lane 3: non-parasitized gills of $T$ decussatus; lane 4: abscesses from parasitized gills of $T$. semidecussatus. The migration positions of molecular mass standards are indicated in $\mathrm{kDa}$ on the left. In addition, the position of band p225 is indicated on the right

In the infiltrated granulocytes, labeling by the serum against $p 225$ was restricted to granules. Ultrastructural characteristics and LD of the granules were variable according to the maturation stage of the granulocytes. Granulocytes in early and medium stages of maturation showed the cytoplasm filled by granules with a similar size, homogeneous content and devoid of internal membranes. The LD for these granules was high and the label was uniformly distributed (Figs. 6 \& 7). Autophagosomes with low LD were characteristic of intermediate maturation stages (Fig. 8). Granulocytes that lay at the periphery of the cellular reaction showed immature granules and were similar to the circulating granulocytes. These granules were identified by their uniform size, floccular content, absence of internal membranes and low LD (Fig. 9).

Mature granulocytes, located in the inner regions of the cellular reaction, were typified by a regression of the endomembranous compartment and the presence of granules with a variable size, dense content, internal membranes and high LD $(70.6 \pm 9.4$ gold particles $\mu \mathrm{m}^{-2}$ ). This LD was nevertheless significantly lower than LD obtained for the mature granules of Tapes semidecussatus $\left(116.9 \pm 11.5\right.$ gold particles $\left.\mu^{-2}\right)$ (Table 1). Giant granules resulting from fusion were occasionally observed in these mature granulocytes (Fig. 10). The LD for these giant granules was lower than the LD for unfused mature granules. On the other hand, some mature granulocytes were observed with a single granule that enclosed all granules in the cell. 

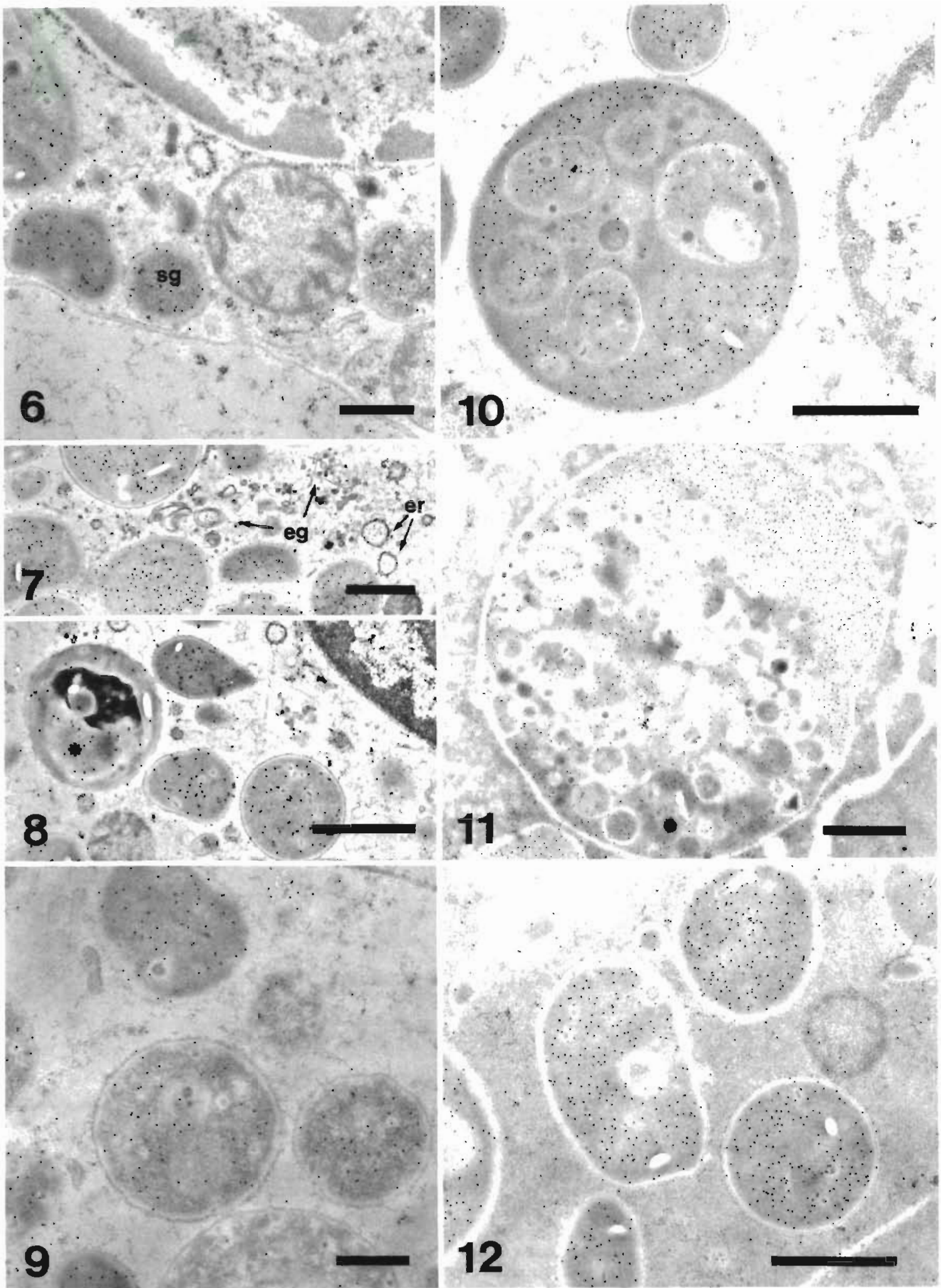

Figs. 6 to 12. Tapes decussatus parasitized by Perkinsus sp. Immunolocalization of granulocyte structures of $T$ decussatus that react with the serum against p225 from $T$. semidecussatus. Fig. 6 . Granulocyte cytoplasm filled by membrane-bound secretion granules $(\mathrm{sg})$. The granule content is the only structure labeled. $\times 23000$. Scale bar $=0.5 \mu \mathrm{m}$. Fig. 7 . Endomembranes from a granulocyte. Rough endoplasmic reticulum (er), endosome/golgi vesicles (eg) and labeled secretion granules. $\times 11000$. Scale $\mathrm{bar}=1 \mu \mathrm{m}$. Fig. 8. Autophagosome (asterisk) with internal membranes, heterogeneous content and weak, scattered label from a granulocyte in the late stages of differentiation. $\times 16000$. Scale bar $=1 \mu \mathrm{m}$. Fig. 9. Labeled immature granules of the granulocytes, showing a floccular content. $\times 23000$. Scale bar $=0.5 \mu \mathrm{m}$. Fig. 10 . Several small granules contained in a large granule

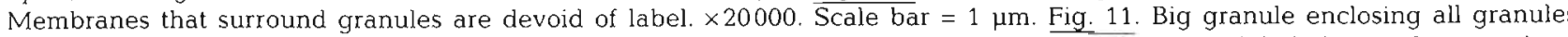
of a granulocyte. Label is heterogeneously distributed. $\times 13000$. Scale bar $=1 \mu \mathrm{m}$. Fig. 12 . Strongly labeled granules contained in the gelated cytoplasm from a pre-secretory granulocyte. $\times 2 \overline{2000}$. Scale bar $=1 \mu \mathrm{m}$ 
Table 1. Label density expressed as number of gold particles $\mu \mathrm{m}^{-2}$ labelling p225 in mature granules and in capsules from both Tapes semidecussatus and $T$ decussatus parasitized by Perkinsus sp. Values are means \pm SEM from at least 30 measurements performed on 3 specimens for each clam species The significance of mean differences between groups was tested by ANOVA; $F=5.03$

\begin{tabular}{|lcc|}
\hline & T. semidecussatus & T. decussatus \\
\hline Mature granules & $116.9 \pm 11.5$ & $70.6 \pm 9.4 \cdots$ \\
Capsule & $107.1 \pm 9.1$ & $51.5 \pm 11.8 \cdot$ \\
$\cdots p<0.01$ and $\cdots p<0.001$ comparing values in homolo- \\
gous compartments from both species \\
\hline
\end{tabular}

These singie granuies, which showed a heterogeneous content and Iabeling (Fig. 11), constituted intermediate stages between giant granules and autophagosomes, and were never secreted around the trophozoites or the capsule. Finally, late stages of granulocyte maturation were sometimes characterized by gelation of the cytoplasm, leading to the formation of a matrix around the granules, which showed high LD (Fig. 12).

By electron microscopy, the trophozoites were characterized by the presence of a euchromatic nucleus, positioned eccentrically, which contained a large nucleolus; in addition, the vacuolar compartment was constituted by a voluminous vacuole and some smaller elements placed in the peripheral cytoplasm (Figs. 13, $14 \& 15)$. Furthermore, mitochondria with an expanded matrix, cisternae of endoplasmic reticulum, polysomes, an endomembranous network and lipid droplets were recognized. Trophozoites were surrounded by a homogeneous thin wall (Fig. 13).

Trophozoites were frequently enclosed by a capsule (Figs. 13, $14 \& 16$ ) which originated from the holocrine secretion of the infiltrated granulocytes. As a consequence of this, the outermost regions of the capsule were characterized by the presence of unfused granules and remnants of granulocyte membranes (Fig. 14). On the other hand, the innermost regions of the capsule showed an amorphous content with remnants of granule membranes and. frequently, paracrystalline inclusions (Fig. 16). Finally, dead trophozoites were observed in advanced stages of encapsulation (Fig 16). The capsule and the trophozoite wall were labeled by the serum (Figs. 13, 14 \& 16). The LD for the capsule was similar to that observed in the granules of both species (Table 1). Moreover, the LD obtained for Tapes semidecussatus was higher than that obtained for $T$. decussatus (Table 1 ).

Finally, trophozoites were observed, in some instances, surrounded by a dense matrix lined by the plasma membrane of the granulocytes (Fig. 15). This matrix contained round cisternae of endoplasmic retic- ulum and residual bodies, which were labeled by the serum. In these cases, the trophozoite wall was devoid of label (Fig. 15), thus indicating that the labeling frequently observed in the trophozoite wall (Figs. 13, 14 \& 16) was a consequence of diffusion processes of this polypeptide.

\section{DISCUSSION}

Several species belonging to the genus Perkinsus have been described as disease agents in infectious processes affecting several molluscan species (Lauckner 1983, Perkins 1988, 1993). These infections are characterized by high mortalities of the host species. In the preseni siudy, we slluw lihe similanities between the defensive responses, at both the cellular and molecular level, that 2 venerid clams present against the parasitism by Perkinsus sp

The butterfish clam Tapes decussatus is a native species from European coasts and closely related with the Manila clam $T$. semidecussatus. The Manila clam was introduced into Europe from natural Indo-Pacific populations for commercial purposes, since its size and growth rate are greater than those of $T$. decussatus. Although these venerid species are phenotypically similar, they constitute 2 distinct entities with a reproductive mating barrier (Gérard 1978), striking karyological differences and high genetic distance (Borsa \& Thiriot-Quiévreux 1990).

Azevedo (1989) described the trophozoites parasitizing Tapes decussatus from Portugal as a new species of the genus Perkinsus, $P$. atlanticus. This differs from the other known species, $P$. marinus (Mackin et al. 1950), P. olseni (Lester \& Davis 1981) and $P$. karIssoni (McGladdery et al. 1991), in zoospore ultrastructure, host identity and host response. The structural characteristics of the trophozoites and defensive responses noted in $T$. decussatus and $T$. semidecussatus (Montes et al. 1995a) from the Spanish Mediterranean coast indicate that this parasite is homologous to $P$. atlanticus.

In Perkinsus sp.-parasitized Tapes decussatus from Portugal, Comps \& Chagot (1987) and Chagot et al. (1987) reported an uncommon host reaction in comparison with those described in other molluscs against infectious agents. The host reaction consisted of an inflammatory response by infiltrated granulocytes with PAS-positive granules, in which the trophozoites were frequently encysted by a PAS-positive substance. Recently, we have described a similar host reaction in $T$. semidecussatus from the Spanish Mediterranean coast. The Manila clam reacts against parasitism by Perkinsus sp. trophozoites by recruiting blood granulocytes, which redifferentiate and constitute a cellular 

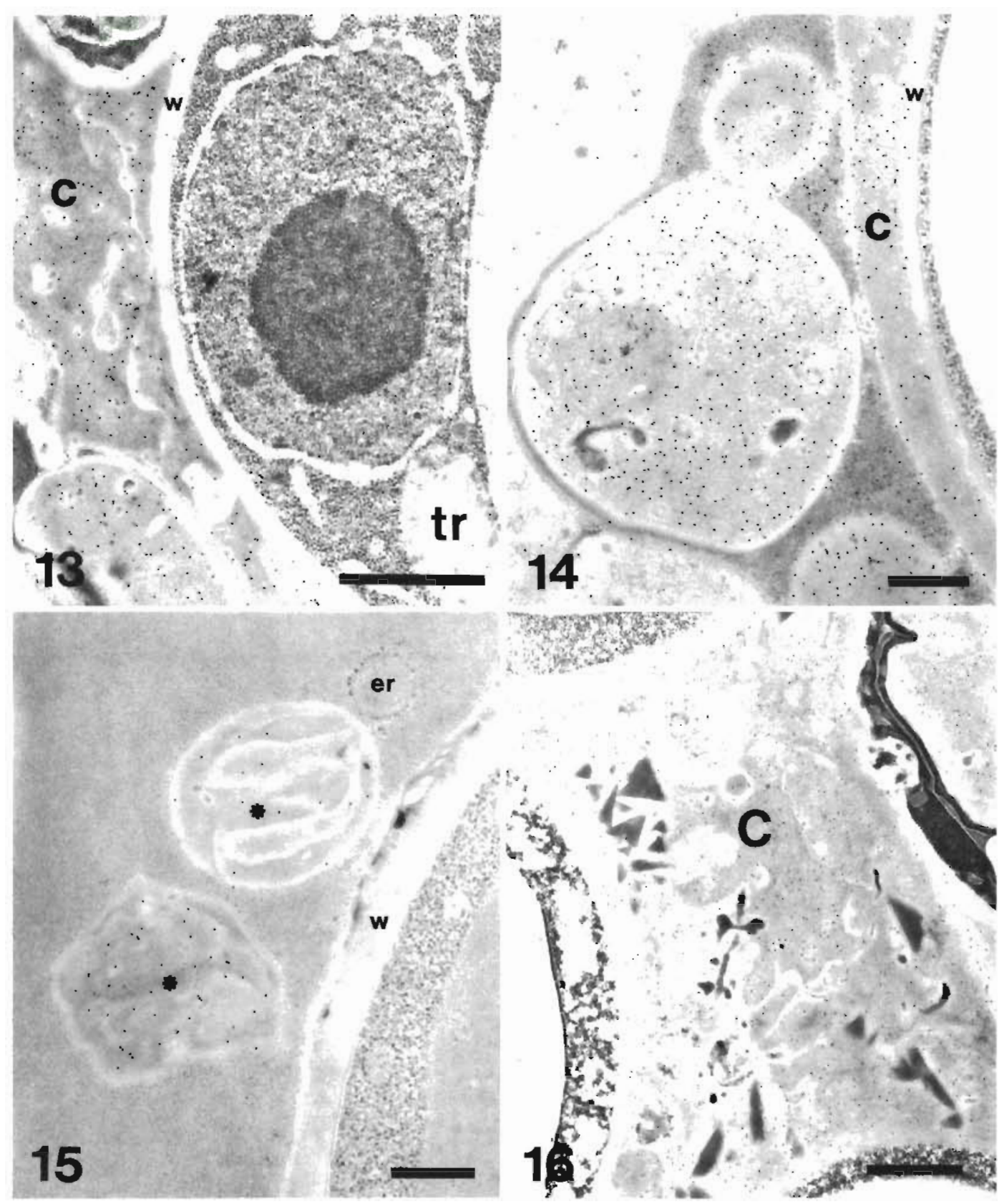

Figs. 13 to 16. Tapes decussatus parasitized by Perkinsus sp. Immunolocalization of trophozoite-associated structures that react with the serum against p225. Fig. 13. Labeling in the capsule that surrounds a Perkinsus sp. trophozoite (tr). The internal membranes of the capsule (c) are devoid of label. Amount of label in the trophozoite wall $(w)$ is low but significant. $\times 20000$. Scale bar $=1 \mu \mathrm{m}$. Fig. 14. Labeled unfused granules in the outermost region of the capsule (c), adjacent to the trophozoite wall (w). $\times 23000$. Scale bar $=0.5 \mathrm{~mm}$. Fig. 15. Trophozoite in close contact with a granulocyte that shows gelated cytoplasm and that contains labeled residual bodies (asterisks) and remnants of rough endoplasmic reticulum (er). Trophozoite wall (w) was unlabeled. $\times 23000$. Scale bar $=0.5 \mu \mathrm{m}$. Fig. 16. Trophozoites at several stages of disorganization, surrounded by a labeled capsule (c) that shows internal membranes and paracrystalline structures. $\times 13000$. Scale bar $=1 \mu \mathrm{m}$

reaction (Montes et al. 1995a). These infiltrated cells synthesize and secrete their main product, a slightly glycosylated polypeptide of about $225 \mathrm{kDa}$ (p225), which encapsulates the parasites (Montes et al. 1995b). The cellular reaction is functionally polarized and its secretion is exclusively located around the trophozoites.

The cellular reaction of Tapes decussatus against Perkinsus sp. trophozoites showed the same characteristics described for $T$. semidecussatus (Montes et al. 
1995a). The reactive cells are infiltrated granulocytes that redifferentiate and synthesize a secretory product, stored in membrane-bound granules, which encapsulates the parasites. However, the cellular reaction of $T$. semidecussatus was organized into individualized areas separated by connective tissue, consisting of specific cells (spindle-shaped connective granulocytes) and intermingled fibres, whereas in $T$. decussatus, the cellular reaction was formed by a single cell mass, without elements from the connective tissue.

Infiltrated granulocytes of Tapes decussatus showed a considerable set of endomembranes, such as large mitochondria and round cisternae of the endoplasmic reticulum, that were not seen in the Manila clam. Granules from the butterfish clam did not show the parallel arrays of the internal membranes that are characteristic in $T$. semidecussatus. In some cases, granulocyte granules from $T$. decussatus showed early fusion, giving rise to a single, giant, secretory granule This fusion was concurrent with the loss of water, which led to the gelation of the cytoplasm.

The organization of the capsule around the trophozoites showed the same characteristics in both clams. However, those from Tapes decussatus were sometimes incomplete, and the parasites were only partially encapsulated. It is interesting to point out that the percentage of dead trophozoites relative to total encapsulated parasites was lower for $T$. semidecussatus than for $T$. decussatus 11 and $36 \%$ respectively; data not shown). These data are consistent with the results obtained by Rodriguez et al. (1994), who stated that Perkinsus atlanticus spreads more easily into $T$ semidecussatus than $T$. decussatus after infection by zoospores.

The p225 from Tapes semidecussatus and the polypeptide from $T$. decussatus exhibit strong homology. First, both polypeptides have a similar apparent molecular mass, and that from $T$. decussatus cross-reacts with the serum against p225 from $T$. semidecussatus. Second, at the cellular level, both are synthesized by infiltrated granulocytes and show the same pattern of synthesis, storage and secretion. Third, at the physiological level, both synthesis products are organized as a capsule around the trophozoites. Finally, the nonparasitized specimens were devoid of the respective polypeptides (Montes et al. 1995b).

Moreover, regardless of the nature and mechanism of the clam infection by Perkinsus sp., these results allow us to speculate about the organization of the cellular reaction and the encapsulation of the trophozoites (Montes et al. 1995a). Once the parasites have reached the connective tissue of these clam species, hemocytes are recruited. Under parasite induction these hemocytes redifferentiate, giving rise to secretory granulocytes. These constitute the cellular reaction around the trophozoites, which are encapsulated by the holocrine secretion of the granulocytes. This encapsulation could block trophozoite dissemination (Rodríguez \& Navas 1992, 1995, Montes et al. 1995a), even though this cellular reaction could obliterate the blood sinuses of the clam and, thus, be the eventual cause of the host death (Montes et al. 1995a)

In conclusion, we demonstrate for the first time 2 polypeptides specifically related to clam defense against infection by Perkinsus sp. These 2 polypeptides are not only closely related at the molecular and the functional level, but are also a specific product of the reactive connective tissue.

Acknowiedgements. Wie are gratefui to Mis Merce Santmartı (Direcció General de Pesca Maritíma, Generalitat of Catalonia, Spain) for providing specimens for this study, to Ms Almudena García and the staff of Serveis Cientifico-Tècnics (Universitat de Barcelona) for technical assistance and to $\mathrm{Mr}$ Robin Rycroft for linguistic advice. This work was supported in part by a grant from the Institut d'Estudis Catalans.

\section{LITERATURE CITED}

Alberts $B$, Bray $D$, Lewis J, Raff $M$, Roberts $K$, Watson JD (1994) The immune system. In: Molecular biology of the cell. Garland Publishing Inc, New York, p 1196-1254

Azevedo $C$ (1989) Fine structure of Perkinsus atlanticus n. sp. (Apicomplexa, Perkinsea) parasite of the clam Ruditapes decussatus from Portugal. J Parasitol 75(4):627-635

Bachère E, Mialhe E, Noël D, Boulo V, Morvan A, Rodriguez $J$ (1995) Knowledge and research prospects in marine mollusc and crustacean immunology. Aquaculture 132: $17-32$

Borsa P. Thiriot-Quiévreux C (1990) Karyological and allozymic characterization of Ruditapes philippinarum, $R$. aureus and $R$. decussatus (Bivalvia, Veneridae). Aquaculture 90:209-227

Carlemalm E, Garavito RM, Villiger W (1982) Resin development for electron microscopy and an analysis of embedding at low temperature. J Microsc 126:123-143

Chagot D, Comps M, Boulo V, Ruano F, Grizel H (1987) Histological study of a cellular reaction in Ruditapes decussatus infected by a protozoan. Aquaculture 67:260-261

Chintala MM, Ford SE, Fisher WS, Ashton-Alcox KA (1994) Oyster serum agglutinins and resistance to protozoan parasites. J Shellfish Res 13(1):115-121

Comps $M_{1}$ Chagot D (1987) Une parasitose nouvelle chez la palourde Ruditapes decussatus L. CR Acad Sci Paris (III) $304(1): 41-44$

Da Ros L, Canzonier WJ (1985) Perkinsus, a protistan threat to bivalve culture in the Mediterranean. basin. Bull Eur Ass Fish Pathol 5(2):23-25

Figueras A, Robledo JAF, Novoa B (1992) Occurrence of haplosporidian and Perkinsus-like infections in carpetshell clams, Ruditapes decussatus (Linnaeus, 1758), of the Ria de Vigo (Galicia, NW Spain). J Shellfish Res 11(2): $377-382$

Gérard A (1978) Recherches sur la variabilité de diverses populations de Ruditapes decussatus et Ruditapes philippinarum (Veneridae, Bivalvia). PhD thesis, University of Bretagne Occidentale, Brest 
Goggin CL (1992) Occurrence of parasites of the genus Perkinsus in France. Bull Eur Ass Fish Pathol 12(5):174-176

González V. Peñas J, Díaz A (1987) Deermocystidiosis en almeja fina portuguesa de importación. Cuad Marisq Publ Téc 12:695-700

Laemmli UK (1970) Cleavage of structural proteins during the assembly of the head of bacteriophage T4. Nature 227 : $680-685$

Lauckner G (1983) Diseases of Mollusca: Bivalvia. In: Kinne O (ed) Diseases of marine animals, Vol 2, Bivalvia to Scaphopoda. Biologische Anstalt Helgoland, Hamburg, p $520-615$

Lester RJG, Davis GHG (1981) A new Perkinsus species (Apicomplexa, Perkinsea) from the abalone Haliotis ruber. J lnvertebr Pathol 37:181-187

Levine ND (1978) Perkinsus gen. n. and other new taxa in the protozoan phylum Apicomplexa. J Parasitol 64(3):549

Mackin JG, Owen HM, Collier A (1950) Preliminary note on the occurrence of a new protistan parasite, Dermocystidium marinum n. sp. in Crassostrea virginica (Gmelin). Science 111:328-329

McGladdery SE, Cawthorn RJ, Bradford BC (1991) Perkinsus karlssoni n. sp. (Apicomplexa) in bay scallops Argopecten irradians. Dis Aquat Org 10:127-137

Merril CR, Goldman D, Sedman SA, Ebert MH (1981) Ultrasensitive stain for proteins in polyacrylamide gels shows regional variation in cerebrospinal fluid proteins. Science 211:1437-1438

Montes JF, Durfort M, García-Valero J (1995a) Cellular defence mechanism of the clam Tapes semidecussatus against infection by the protozoan Perkinsus sp. Cell Tissue Res 279:529-538

Montes JF, Durfort M, García-Valero J (1995b) Characterization and localization of an Mr $225 \mathrm{kDa}$ polypeptide specifically involved in the defence mechanisms of the clam Tapes semidecussatus. Cell Tissue Res 280:27-37

Navas Jl, Castillo MC, Vera P, Ruiz-Rico M (1992) Principal parasites observed in clams, Ruditapes decussatus (L.), Ruditapes philippinarum (Adams et Reeve), Venerupis

Responsible Subject Editor: A. K. Sparks, Seattle, Washington, USA pullastra (Montagu) and Venerupis aureus (Gmelin), from the Huelva coast (S.W. Spain). Aquaculture 107: 193-199

Perkins FO (1988) Structure of protistan parasites found in bivalve molluscs. Am Fish Soc Spec Pub] 18:93-111

Perkins FO (1993) Infectious diseses of molluscs. In: Couch JA, Fournie JW (eds) Advances in fisheries science. Pathobiology of marine and estuarine organisms. CRC Press, Boca Raton, p 255-287

Rodríguez F, Godoy T, Navas JI (1994) Cross-infection with Perkinsus atlanticus in Ruditapes decussatus, Ruditapes philippinarum and Venerupis pullastra. Bull Eur Ass Fish Pathol 14(1): $24-27$

Rodríguez F, Navas JI (1992) A comparison of gill and hemolymph assays for the thioglycollate diagnosis of Perkinsus atlanticus in clams, Ruditapes decussatus and Ruditapes philippinarum. Proc PAMAQ 5:66

Rodríguez F, Navas JI (1995) A comparison of gill and hemolymph assays for the thioglycollate diagnosis of Perkinsus atlanticus (Apicomplexa, Perkinsea) in clams, Ruditapes decussatus (L.) and Ruditapes philippinarum (Adams et Reeve). Aquaculture 132:145-152

Sagristà E, Durfort M, Azevedo C (1991) Ultrastructural study of the life cycle of Perkinsus sp. (phylum Apicomplexa), parasite of a Mediterranean clam. Coloq Franco-Ibérico Microsc Elec 1:145-146

Sagristà E, Durfort M, Azevedo C (1995) Perkinsus sp. (Phylum Apicomplexa) in Mediterranean clam Ruditapes semidecussatus: ultrastructural observations of the cellular response of the host. Aquaculture 132:153-160

Towbin H, Staehelin T, Gordon J (1979) Electrophoretic transfer of proteins from polyacrylamide gels to nitrocellulose sheets: procedure and some applications. Proc Natl Acad Sci USA 76:4350-4354

Villalba A, Navas JI (1988) Occurrence of Minchinia tapetis and a Perkinsus-like parasite in cultured clams, Ruditapes decussatus and $R$. philippinarum, from south Atlantic coast of Spain. Preliminary results. Proc PAMAQ 3: 57-58

Weibel ER (1979) Stereological methods, Vol 1 Academic Press, New York

Manuscript first received: June 6, 1995

Revised version accepted: January 30, 1996 